\title{
Detection and identification of medically important microorganisms isolated from pigeon excreta collected in a university in a newly industrialized country
}

\author{
Alessandra Rejane Ericsson de Oliveira Xavier ${ }^{1 *}$ \\ Léia Cardoso ${ }^{1}$ \\ Ronise Viviane Jorge Brito ${ }^{1}$ \\ Sérgio Avelino Mota Nobre ${ }^{1}$ \\ Anna Christina de Almeida ${ }^{2}$ \\ Alexandre Moisés Ericsson de Oliveira ${ }^{3}$ \\ Mauro Aparecido de Sousa Xavier ${ }^{1}$ \\ ${ }^{1}$ Universidade Estadual de Montes Claros, Center of Biological and Health Science \\ CEP 39401-089, Montes Claros - MG, Brazil \\ ${ }^{2}$ Universidade Federal de Minas Gerais, Montes Claros - MG, Brazil \\ ${ }^{3}$ Universidade Federal de Uberlândia, Uberlândia - MG, Brazil \\ * Autor para correspondência \\ ericsson_aerc@yahoo.com.br
}

Submetido em 28/07/2018

Aceito para publicação em 19/12/2018

\section{Resumo}

Deteç̧ão e identificação de microrganismos de importância médica isolados em fezes de pombos coletados em uma universidade de um país recém-industrializado. A exposição humana a fezes de animais contaminados com microrganismos patogênicos representa um risco para a saúde. A presença de fungos e leveduras em ambientes está relacionada a efeitos adversos na saúde respiratória. A abordagem objetiva para a mitigação de possíveis efeitos à saúde devido à exposição a fungos e leveduras em ambientes fechados é difícil devido à falta de diretrizes. O objetivo deste trabalho foi conhecer as condições higiênico-sanitárias, identificar e caracterizar microorganismos de importância médica isolados de fezes de pombos coletadas na laje de um telhado de um prédio público. Para tais pontos, a coleta de excrementos foi estabelecida e os microrganismos foram identificados por métodos bioquímicos e microbiológicos padronizados, seguidos da abordagem proteômica de MALDI-TOF para a identificação do nível de espécie. Os resultados da identificação microbiana revelaram a presença de microrganismos de importância médica nas amostras analisadas, a saber: Candida krusei, Candida rugosa, Aspergillus spp., Cryptococcus neoformans, Klebsiella pneumoniae e Trichosporon asahii. Os resultados encontrados revelam a necessidade do desenvolvimento de metodologias que permitam mitigar os riscos à saúde humana devido à exposição a agentes patogênicos no ambiente examinado.

Palavras-chave: Carga microbiana; Contaminação; Exposição; Fezes de animais; MALDI-TOF; Mitigação de risco 


\section{Abstract}

Exposure to animal feces contaminated with pathogenic microorganisms poses a risk to human health. The presence of fungi and yeasts in environments is related to adverse effects on respiratory health. An objective approach to mitigating possible health effects due to exposure to fungi and yeasts in closed environments is difficult due to the lack of guidelines. The aim of this work was, to identify and characterize microorganisms of medical importance isolated from pigeon feces collected on roof tiles of a university building and also to evaluate the hygienic-sanitary conditions of the study area. Excrement sampling points were established, and the microorganisms were identified by standard biochemical and microbiological methods followed by MALDI-TOF proteomics for identification at the species level. Microbial identification revealed the presence of medically important microorganisms in the samples analyzed, namely the fungi Candida krusei, Candida rugosa, Aspergillus spp., Cryptococcus neoformans and Trichosporon asahii and bacterium Klebsiela pneumoniae. The results obtained demonstrated the need for the development of methods that help mitigate risks to human health due to exposure to pathogenic agents in environments such as that studied.

Key words: Animal feces; Contamination; Exposure; MALDI-TOF; Microbial load; Risk mitigation

\section{Introduction}

Exposure to bacteria, fungi and yeasts in closed environments is an important public health problem. In particular, scientific knowledge on the subject of "effects of fungi and yeasts on health" is still rare in many areas. The microbial growth in closed environments is a potential risk for health, even without a quantitative and or casual association between the occurrence of fungi/yeasts species and their effects on health. A few specialists have the necessary knowledge about possible risks to human health from exposure to fungi and yeasts in closed environments, and the diagnosis and treatment of diseases caused by exposure to these microorganisms (CRAWFORD et al., 2015; HURRAßet al., 2017).

The objective approach to mitigate possible health effects due to exposure to fungi and yeasts in closed environments is difficult due to the lack of guidelines (CRAWFORD et al., 2015; HURRA $\beta$ et al., 2017). In April 2016, the German Society of Hygiene, Environmental Medicine and Preventive Medicine, along with other medical societies from Germany and Austria, doctors and specialists from the AWMF (Association of the Scientific Medical Societies in Germany) developed a guide entitled "Medical diagnosis for indoor mold exposure." This document provides important information that can be used to mitigate risks from exposure to fungi and yeasts in closed environment, and an introductory course as well for patients subjected to this exposure (HURRA $\beta$ et al., 2017).
Public buildings, monuments and homes can have an accumulation of animal excrement, for example, pigeon, bat and rodent feces. The literature points out the problems encountered by the accumulation of feces, feathers and nest remnants, which can lead to clogging of rain drainage systems, to compromise of various equipment and to risks of contamination of water supplies and food (CONTIN et al., 2011). Animals existing near humans in developing countries harbor many pathogens capable of infecting humans through feces. Contact with animal feces represents a risk that is not currently quantified but that is probably substantial to human health (DELAHOY et al., 2018).

The role of pigeons and other birds as carriers of pathogens of importance to public health, such as protozoa, fungi, yeast, bacteria and viruses is well established. In a special way, pigeons are birds that play an important role as carriers of species of Cryptococcus, particularly Cryptococcus neoformans. However, Cryptococcus is not the only fungal genus that is a concern to public health, since several diseases involving other yeasts are described in the literature, including Candida species and other emerging pathogens such as Malassezia furfur, Trichosporon asahii, Rhodotorula species, and Wickerhamomyces anomalus (FORASTIERO et al., 2015; MEDINA et al., 2017).

The objective of this work was to identify and characterize microorganisms of medical importance isolated from animal excreta collected from a roof tile 
of a university building in a newly industrialized country and to determine the hygienic-sanitary conditions of the study area.

\section{Materials and Methods}

\section{Sampling and pigeon excreta and isolation of microorganisms}

The sampling site was a $900-\mathrm{m}^{2}$ building at a Brazilian university attended by approximately 1,000 individuals per day, including students, professors, administrative staff, patients, and service providers. The hygienic-sanitary conditions of the site were evaluated by the method of visual inspection, with photographic and video recording, of the delimited area of study. Excreta was collected at 10 sampling points chosen in an area of approximately $30 \mathrm{~m}^{2}$ on the roof of the building (Figure 1). The rationale for the sampling this area was that the same hygienic-sanitary conditions were observed in the whole area $\left(900 \mathrm{~m}^{2}\right)$ The pigeon excreta samples were collected in sterile plastic tubes and stored in the refrigerator for 24 hours. A 0.5 -g portion of the samples was suspended in 5 $\mathrm{mL}$ of sterile $0.9 \%$ sodium chloride. The tubes were vortexed for three minutes and allowed to stand for 30 minutes at ambient temperature. The supernatant was then aspirated and $100 \mu \mathrm{L}$ inoculated, in triplicate, in Petri dishes with Sabouraud dextrose agar, BHI agar or rose bengal agar plus $40 \mathrm{mg} / \mathrm{L}$ chloramphenicol. The plates were incubated at $30 \pm 2{ }^{\circ} \mathrm{C}$ and observed daily for 3 to 5 days. The colonies were counted and morphologically analyzed, and the counts were logtransformed and recorded in a specific form.

FIGURE 1: Location of sampling points. Panel A: Photographic record of the 10 sites sampled. Points 1 to 10 show the places where pigeon excreta were collected. Pigeon feces, feathers and eggs can be observed at the sampling points, and live pigeons as well. Panel B: Low plants at the sampling site. The red dot indicates the location of the university building where the samples were collected in a total delimited area of approximately $30 \mathrm{~m}^{2}$.
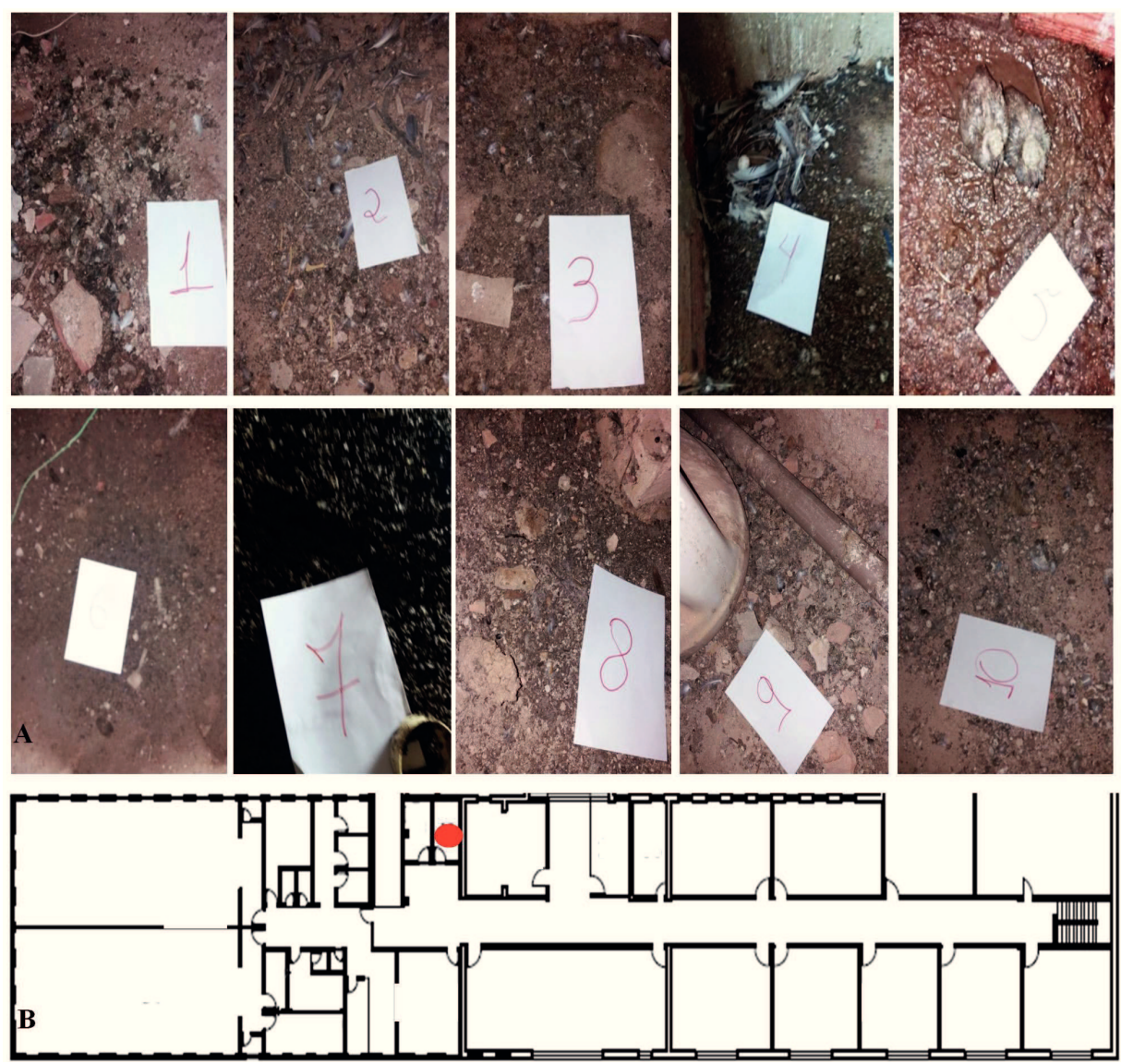
Identification of isolated microorganisms to genus level

Colonies were selected macroscopically characterized as fungi, yeasts, and bacteria for microscopic analysis. The isolates were submitted to direct examination of the colonies under the microscope. The bacteria were subjected to Gram stain, the fungi to lactophenol cotton blue stain and yeasts to methylene blue stain followed by with Indian ink staining as recommended by the National Agency of Sanitary Surveillance (LEVY, 2004). Yeasts that showed capsulation with Indian ink staining were subjected to the urease test. Accordingly, they were transferred to urease agar slant tubes and incubated at $30^{\circ} \mathrm{C}$ for five days. The $\mathrm{pH}$ indicator in the medium turned red for positive results and was yellow for negative. The whole procedure was performed in accordance with the Sanitary Surveillance guide for detection and identification of fungi of medical importance (LEVY, 2004).

A total of 27 colonies were selected and identified by standard microbiological methods, light microscopy, and biochemical tests as belonging to genera of fungi, yeasts, and bacteria of medical importance (at least 1 from each of the 10 points). These microorganisms were subjected to proteomics identification for determining the level of species by MALDI-TOF mass spectrometry.

\section{Proteomics identification of selected microorganisms by MALDI-TOF}

Cryopreserved specimens were thawed in Sabouraud dextrose medium with $40 \mathrm{mg} / \mathrm{L}$ chloramphenicol and grown for 24 hours at $30^{\circ} \mathrm{C}$. A single colony of each microbial strain was spotted using a toothpick on the target steel plate. For each strain, $1 \mu \mathrm{L}$ of formic acid (70\%) and $1 \mu \mathrm{L}$ of MALDI-TOF MS matrix, consisting of a saturated solution of a-cyano-4-hydroxycinnamic acid (HCCA) (Bruker Daltonics, Bremen, Germany), were applied to the spot, and the mixture allowed to air-dry. Spectra were acquired using the FlexControl MicroFlex LT mass spectrometer (Bruker Daltonics) with a $60-\mathrm{Hz}$ nitrogen laser, in which up to 240 laser shots were fired in spiral movements to collect 40 shot steps for each strain spot. Furthermore, parameters for mass range detection were defined to allow the identification of 1,960 to $20,137 \mathrm{~m} / \mathrm{z}$, where ion source 1 voltage was $19.99 \mathrm{kV}$, ion source 2 voltage was $18.24 \mathrm{kV}$ and the lens voltage was $6.0 \mathrm{kV}$ for data acquisition. Prior to measurements, calibration was performed with a bacterial test standard (Escherichia coli DH5 alpha; Bruker Daltonics). The real-time (RT) identification score criteria used were those recommended by the manufacturer: score $\geq 2.000$ indicates species-level identification, score $\geq 1.700$ and $<2.000$ indicates genus-level identification and a score $<1.700$ indicates no reliable identification. Comparisons between MALDI-TOF MS strain identifications and those with other techniques were performed with $\mathrm{R}$ software, version 3.0.1 (R CORE TEAM, 2013) with the agreement rates determined by the Kappa coefficient.

\section{Data analysis}

The data obtained for total count of viable microorganisms and the results of the identification of microorganisms were transferred to an Excel spreadsheet and displayed as graphs and tables.

\section{Results and Discussion}

The overview of the hygienic-sanitary conditions of the site on the collection date is shown in Figure 2A. The conditions proved to be inappropriate, since carcasses of dead animals, feathers, bones, live pigeons, eggs of pigeons, and a thick layer of excreta were found as a potential source of environmental contamination. After ten days of sampling, there was rain, which carried this material into the laboratories and classrooms due to roof leaks. Figure 2B shows the presence of mold growing on the walls and ceilings of these environments. Although these microorganisms growing there were not collected and identified (visual inspection and photographic recording only), common sense indicates the potential of these molds to cause respiratory diseases and allergies. Epidemiological studies measure exposure to moisture and mold by indirect methods such as, for questioning the occupants or by inspection of the inside conditions of a place (GUNNBJÖRNSDÓTTIR et al., 2006; FISK et al., 2007; ANTOVA et al., 2008; CRAWFORD et al., 2015). Moisture and mold indicate environments 
FIGURE 2: Hygienic-sanitary conditions of the area where pigeon excreta samples were collected and laboratories near the sampling site. Panel A: Pigeon carcasses, pigeons in the putrefied state, bird bones and live pigeons could be seen at the pigeon excreta sampling site. Panel B: Fungal growth could be observed on the ceiling and workbenches of laboratories below the pigeon excreta sampling site on the roof.
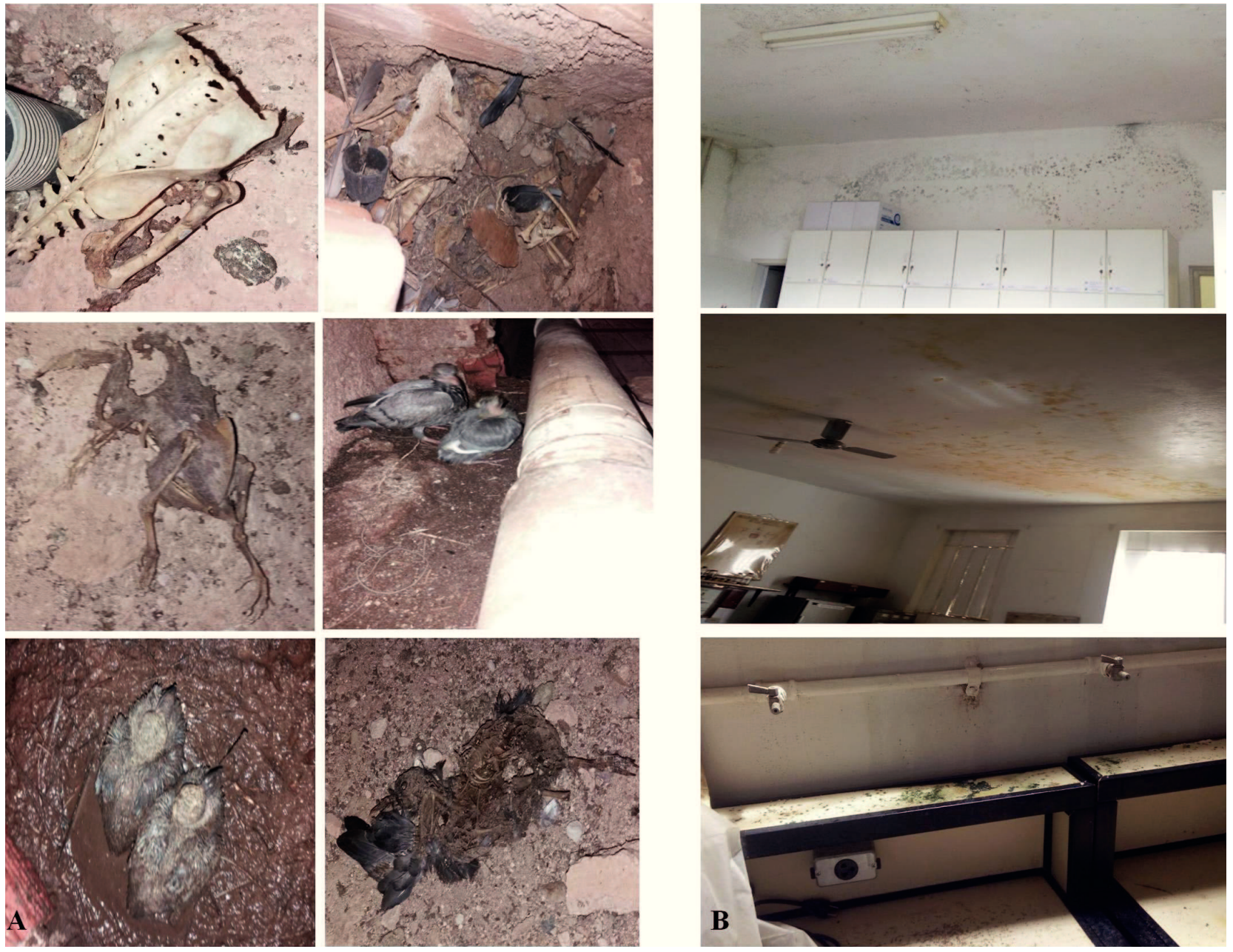

have adverse effects on respiratory health, regardless of the knowledge of microbial agents present. Literature reviews have concluded that exposure to damp and moldy indoor environments is associated with health problems such as wheezing, cough, upper respiratory symptoms and asthma (CRAWFORD et al., 2015; HURRA $\beta$ et al., 2017).

With the objective of identifying possible pathogenic microorganisms in the animal feces studied herein, 90 plates were analyzed (triplicate samples of 10 points in three different culture media) of which $100 \%$ (90/90) showed growth with predominantly colonies of fungi and yeasts, although bacteria were also isolated The total count of viable microorganisms revealed plates with confluent growth (up to $2.48 \mathrm{log} /$ plate). The points A2, A4, A6, A7, A8 and A9 had the highest total counts of viable microorganisms (up to $4.48 \mathrm{log} / \mathrm{g}$ ). However all points showed mean counts exceeding $3.7 \mathrm{log} / \mathrm{g}$ of analyzed excreta (Figure 3). 
FIGURE 3: Total count of viable microorganisms isolated from pigeon excreta inoculated in three different culture media. Sampling points A1 to A10 are shown on the abscissa. The culture media used for isolation of microorganisms are shown in the figure. The ordinate indicates the log-transformed mean total viable count per $g$ of excreta. All experiments were carried out in triplicate.

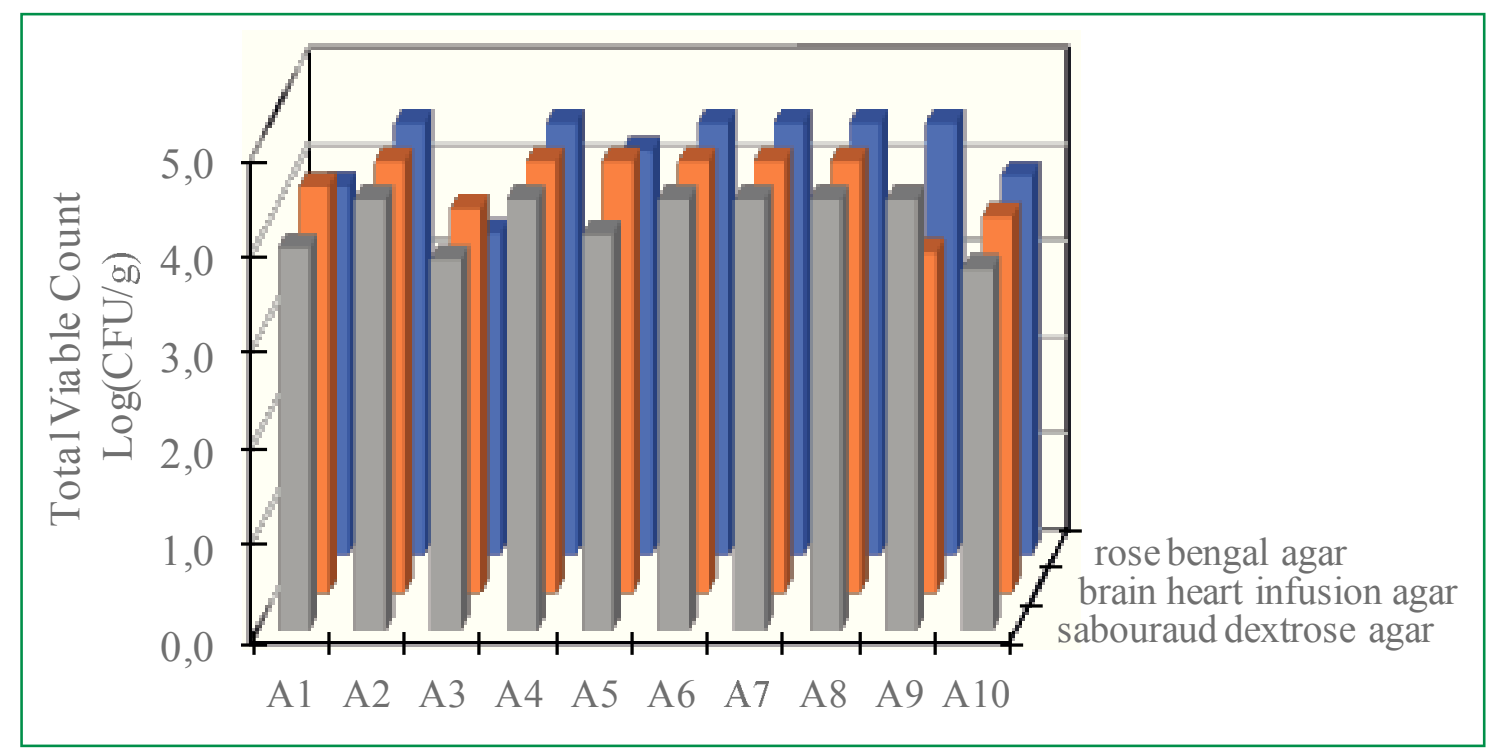

The microscopy analyses of selected colonies of plates of three media containing samples of 10 sampling points showed a prevalence of filamentous fungi and yeasts. However, bacteria were also found in the form of bacilli.

The identification of all isolates was not possible, since there were plates with confluent growth $(>2.48$ $\log$ ) even with the standardized dilution of samples. In addition, among the plates where counting was possible, the identification of all colonies was impracticable due to the large number of CFU present in 90 plates with the 3 different culture media. The selection of only 27 isolates was based on microbiological analyses and microscopic and biochemical tests of the colonies characterized as belonging to genera of medical interest that had been selected for proteomic identification to the species level. However, due to problems related to the MALDI-TOF technique, some microorganisms exhibited a spectrum but could not be identified to the species level because they were not available in the microorganism database of the equipment.

Only $60 \%(16 / 27)$ of the isolates could be identified to the species level. In relation to filamentous fungi, the analysis of fungal morphotyping allowed the identification of the genus Aspergillus in $14 \%$ of the isolates (4/27). Four samples consisting of two filamentous fungi and 2 yeasts could be identified just by general macroscopic and microscopic characteristics (yeast cells/filamentous fungi). Figure 4 shows the general results of microbiological and proteomics identifications for the 27 environmental isolates of excreta of animals, including the pigeons. Fungi and yeasts were more prevalent than bacteria; however, $15 \%$ of the isolates corresponded to the Gram-negative bacterium Klebsiella pneumoniae. This microorganism is an opportunistic pathogen associated with both community and nosocomial infections, including pneumonia, urinary tract infections and septicemia, and with a significant increase in multidrug resistance, which is considered a major public health problem (CAO et al., 2014).

Among the yeasts identified to the species level, Candida krusei (19\%) was the most frequently found (Figure 4). This yeast is known to be the causative agent of the spread of fungal infections in susceptible patients, resulting in lower rates of survival of 90 days (53.6\%) among the Candida. Although the prevalence of Candida krusei remains low (2\%) among the fungal 
FIGURE 4: Results of the identification of medically important microorganisms isolated from pigeon excreta collected on the roof of a university building in Brazil.

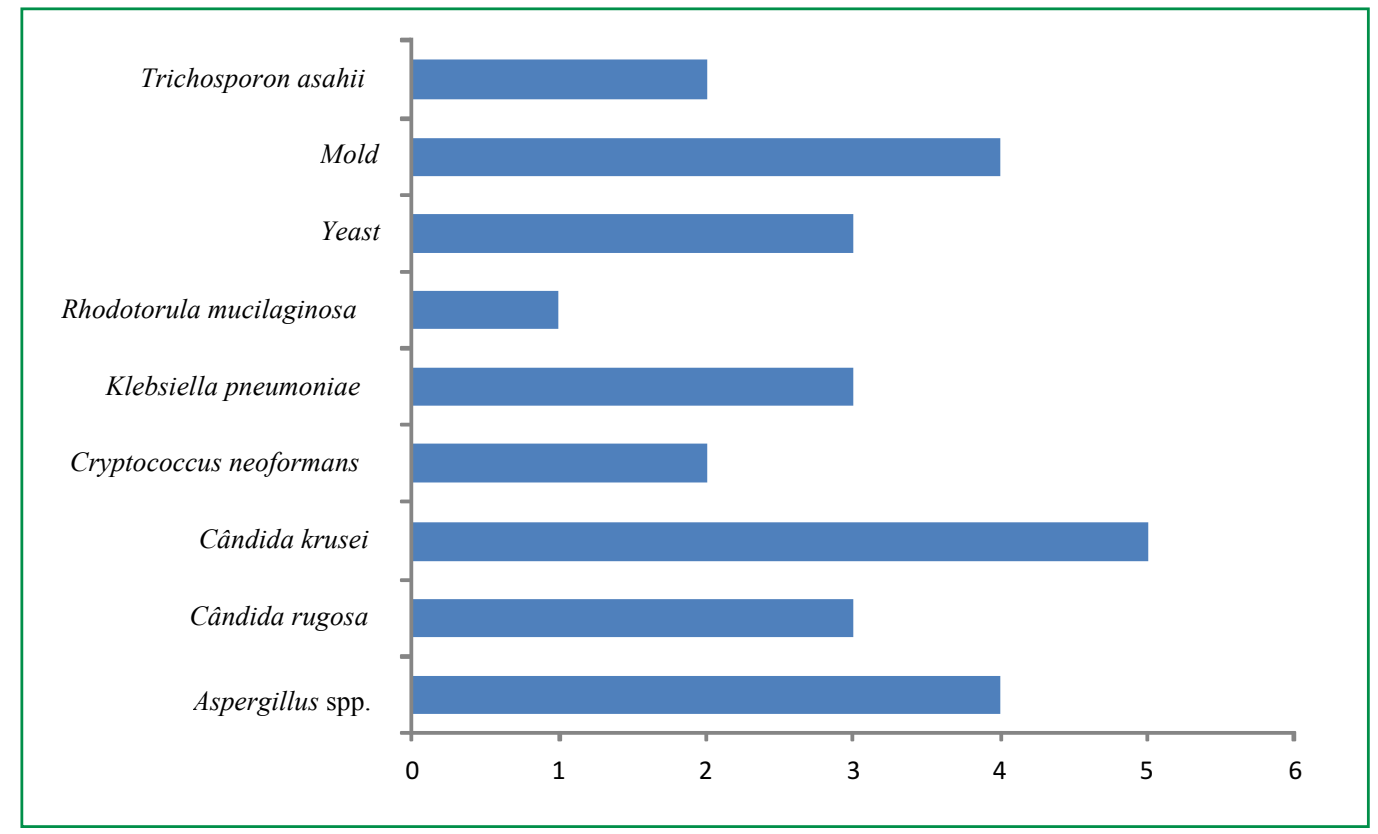

infections, their intrinsic resistance to fluconazole and low sensitivity to flucytosine and amphotericin $B$ raises epidemiological and therapeutic concerns (FORASTIERO et al., 2015; PFALLER et al., 2008).

Although it was not identified at the species level, the fungus Aspergillus was the second most abundant microorganism in the selected samples (Figure 4). Aspergillus is a fungus genus of universal distribution in nature. It is the most common source of infection of the airways, and has become as a cause of severe infection with risk of death in immunocompromised patients. This population of patients includes those with advanced HIV infection, prolonged neutropenia and primary immunodeficiency, and lung and bone marrow transplant patients as well (SALES, 2009).

Another fungus of medical importance, Trichosporon asahii, was found in 7\% of samples analyzed in this study (Figure 4). This fungal species is responsible for most cases of trichosporonosis and represents an important opportunistic pathogen agent in hematologic patients. A recent epidemiological analysis of patients with cancer reported an increased incidence of Trichosporon spp. from 1.8 to 2.35 cases per 100 thousand patients. This scenario may be related to intrinsic resistance of the genus Trichosporon to echinocandin-class antifungal drugs administered to neutropenic patients (DUARTEOLIVEIRA et al., 2017).

Yeasts of medical importance were isolated in this work, Candida rugosa (11\%), Cryptococcus neoformans (7\%) and Rhodotorula mucilaginosa (4\%) (Figure 4). Cryptococcus neoformans is an encapsulated yeast of medical importance, because it is the etiologic agent of cryptococcosis. It can be found in environmental sources, including pigeon feces, constituting an important cause of morbidity and mortality in immunocompromised individuals worldwide (CONTIN et al., 2011; DEL POETA; CASADEVALL, 2012; MOLLOY et al., 2017). The risk of being affected by cryptococcosis is 1,000 times higher in HIV-positive individuals when compared with immunocompetent individuals. Centers for Disease Control and Prevention estimates that one million new cases of cryptococcosis in AIDS patients will occur in the world (CENTERS FOR DISEASE CONTROLAND PREVENTION, 2018). It is estimated that 220,000 annual cases of cryptococcal meningitis occur among HIV-positive people in the world, resulting in approximately 181,000 deaths (RAJASINGHAM et al., 2017). Cryptococcus neoformans var. neoformans 
predominates as an opportunistic agent, affecting individuals with impaired cellular immunity, where it is gaining great importance, not only because of population growth, but especially due to the increasing number of susceptible hosts: HIV-positive individuals, leukemia patients, transplanted patients, those with solid tumors, and patients on prolonged use of corticosteroids and antibiotics (FILIÚ et al., 2002).

Infection by Cryptococcus neoformans var. neoformans is acquired through inhalation of propagules of environmental origin, represented by dehydrated yeast, smaller than $2 \mathrm{~mm}$ diameter, easily aerosolized (FILIÚ et al., 2002). The lung is the primary site of infection, which is frequently asymptomatic, characterized by a solitary pulmonary nodule, similar to carcinoma. It may cause symptomatic pneumonia, which is characterized by diffuse pulmonary infiltrates. The yeast can migrate to other parts of the body, showing tropism for the central nervous system (CNS), which leads to meningitis, meningoencephalitis or encephalitis (NISHIKAWA et al., 2003; CONTIN et al., 2011). Other common manifestations of disseminated cryptococcosis include osteolytic bone lesions (DARZÉ et al., 2000; CONTIN et al., 2011).

Candida krusei is described as the causative agent of dissemination of fungal infections in susceptible patients, resulting in lower rates of survival of 90 days (53.6\%) among the Candida species. Although the prevalence of Candida krusei remains low (2\%) among the fungal infections, their intrinsic resistance to fluconazole, low sensitivity to flucytosine and Amphotericin B raises epidemiological and therapeutic concerns (PFALLER et al., 2008; FORASTIERO et al., 2015).

Candida rugosa is an emerging etiological agent of human infectious diseases in different parts of the world. In the last 10 years, it has been described as a cause of candidemia in patients with trauma. Statistics reveals its frequency to be estimated at $0.6 \%$ in the world, with a high prevalence in South America (PFALLER et al., 2008; PADOVAN et al., 2013).

Rhodotorula mucilaginosa is a yeast found in aquatic and terrestrial environments and surfaces of the mucous membranes of animals, including humans. Although it has been previously considered as a nonpathogenic microorganism, this agent is currently recognized as potentially harmful to health, especially in immunocompromised patients, often being directly associated with catheters, prostheses and grafts, endocarditis, peritonitis, and meningitis. More recently, this microorganism has been implicated as the causal agent of onychomycosis (LOSS et al., 2011).

The university building where these yeasts were isolated offers free dental care, provided by students supervised by professors (school-clinical model). Among the patients who use this service are those with immunodeficiencies or dealing with cancer, since the service offered covers the diagnosis of oral alterations. The risk to which these patients and others in this building are exposed must be clarified.

The findings of this study indicate substantial microbial contamination in the environment examined. To date, there are no Brazilian regulations establishing the acceptable limits of microbial contamination in closed environments. This lack of regulation for the mitigation of possible human health risks due to exposure to fungi and yeasts have been a concern for the German Society of Hygiene, Environmental Medicine and Preventive Medicine, as well as other medical societies (CRAWFORD et al., 2015; HURRA $\beta$ et al., 2017). The method used to measure the hygienic-sanitary conditions of the roof of the building studied was visual inspection, but this has proved inadequate for urban buildings. It is worth mentioning that in this building, there is teaching, research, management activities, and particularly the provision of health care to the community through the dental clinics.

The laboratory analyzes showed a high microbial load in the samples, indicating the degree of contamination in the sampled area of $30 \mathrm{~m}^{2}$. As a limitation of this study, only this area was sampled of a total area of $900 \mathrm{~m}^{2}$, and this was due to the absence of guidelines which includes sampling plan for this type of environment. A sampling not only of excreta, but the ambient air (i.e., by active methods of air collection) could assist in the mitigation of biological risk type/risk to health (allergies and or 
diseases) to which people using this building in this university would be exposed, particularly those patients with immunodeficiencies and cancer who seek treatment/ diagnosis in the dental clinics. After rains and as a result of leaking of contaminated water with animal excreta the ceiling of some laboratories and classrooms showed the growth of molds as seen in Figure 2B. Unsanitary and inappropriate conditions for completion of any human activity.

In this work pathogenic microorganisms of medical importance were identified, considered as risk class 2 in accordance with the Brazilian ministerial order No. 2,349, dated September 14, 2017 from the Ministry of Health. However, the degree of classification only considers the possible effects of biological agents to healthy individuals. Individuals with previous disease or using medication, patients with immune disorders, pregnancy or breast-feeding were not considered. Viruses and viable, uncultivable microorganisms due to technical limitations were not investigated.

A numerical risk regarding the environmental microbial load capable of causing health problems cannot be deduced on the basis of current knowledge. Alternatively, a method has been proposed for semiquantitative assessment of risk of sensitization/allergy by fungi in indoor environments (HURRA $\beta$ et al., 2017). The development of methods that allow to quantify and establish the acceptable limits of microbial contamination of indoor environments of residential and commercial buildings is essential for studies on mitigation of risks to human health, from exposure to potential pathogens.

\section{Acknowledgments}

The authors are grateful to the Laboratory of Diagnosis of Aquatic Animal Diseases of the Ministry of Agriculture, Livestock and Supply, Universidade Federal de Minas Gerais, Brazil for support in proteomic MALDI-TOF analysis. Dr. A. Leyva (USA) helped with English editing of the manuscript.

\section{References}

ANTOVA, T.; PATTENDEN, S.; BRUNEKREEF, B.; HEINRICH, J.; RUDNAI, P.; FORASTIERE, F.; LUTTMANN-GIBSON, H.; GRIZE, L.; KATSNELSON, B.; MOSHAMMER, H.; NIKIFOROV, B.; SLACHTOVA, H.; SLOTOVA, K.; ZLOTKOWSKA, R.; FLETCHER, T. Exposure to indoor mould and children's respiratory health in the PATY study. Journal of Epidemiology and Community Health, London, v. 62, p. 708-714, 2008.

CAO, X.; XU, X.; ZHANG, Z.; SHEN, H.; CHEN, J.; ZHANG, K. Molecular characterization of clinical multidrug-resistant Klebsiella pneumoniae isolates. Annals of Clinical Microbiology and Antimicrobials, London, v. 13, p. 1-5, 2014.

CENTERS FOR DISEASE CONTROL AND PREVENTION. $\boldsymbol{C}$. neoformans infection statistics. Disponível em: $<$ https://www. cdc.gov/fungal/diseases/cryptococcosis-neoformans/statistics. html>. Acesso em: 19 fev. 2018.

CONTIN, J. T.; QUARESMA, G. S.; SILVA, E. F.; LINARDI, V. R. Ocorrência de Cryptococcus neoformans em fezes de pombos na cidade de Caratinga , MG - Brasil. Revista Médica Minas Gerais, Belo Horizonte, v. 21, p. 19-24, 2011.

CRAWFORD, J. A.; ROSENBAUM, P. F.; ANAGNOST, S. E.; HUNT, A.; ABRAHAM, J. L. Indicators of airborne fungal concentrations in urban homes: understanding the conditions that affect indoor fungal exposures. Science of the Total Environment, Amsterdam, v. 517, p. 113-124, 2015.

DARZÉ, C.; LUCENA, R.; GOMES, I.; MELO, A. Características clínicas laboratoriais de 104 casos de meningoencefalite criptocócica. Revista da Sociedade Brasileira de Medicina Tropical, Uberaba, v. 33, p. 21-26, 2000.

DEL POETA, M.; CASADEVALL, A. Ten challenges on Cryptococcus and cryptococcosis. Mycopathologia, New York, v. 173, p. 303-310, 2012.

DELAHOY, M. J.; WODNIK, B.; MCALILEY, L.; PENAKALAPATI, G.; SWARTHOUT, J.; FREEMAN, M. C.; LEVY, K.. Pathogens transmitted in animal feces in low- and middle-income countries. International Journal of Hygiene and Environmental Health, Atlanta, v. 221, p. 661-676, 2018.

DUARTE-OLIVEIRA, C.; RODRIGUES, F.; GONÇALVES, S. M.; GOLDMAN, G. H.; CARVALHO, A.; CUNHA, C. The cell biology of the Trichosporon-host interaction. Frontiers in Cellular and Infection Microbiology, Lausanne, v. 7, p. 1-8, 2017.

FILIÚ, W. F. de O.; WANKE, B.; AGÜENA, S. M.; VILELA, V. O.; MACEDO, R. C. L.; LAZÉRA, M. Cativeiro de aves como fonte de Cryptococcus neoformans na cidade de Campo Grande. Mato Grosso do Sul, Brasil. Revista da Sociedade Brasileira de Medicina Tropical, Uberaba, v. 35, p. 591-595. 2002.

FISK, W. J.; LEI-GOMEZ, Q.; MENDELL, M. J. Meta-analyses of the associations of respiratory health effects with dampness and mold in homes. International Journal of Indoor Environment and Health, New York, v. 17, p. 284-296, 2007.

FORASTIERO, A.; GARCIA-GIL, V.; RIVERO-MENENDEZ, O.; GARCIA-RUBIO, R., MONTEIRO, M. C.; ALASTRUEYIZQUIERDO, A.; JORDAN, R.; AGORIO, I.; MELLADO, E. Rapid development of Candida krusei echinocandin resistance during caspofungin therapy. Antimicrobial Agents and Chemotherapy, Washington, v. 59, p. 6975-82, 2015. 
GUNNBJÖRNSDÓTTIR, M. I.; FRANKLIN, K. A.; NORBÄCK, D.; BJÖRNSSON, E.; GISLASON, D.; LINDBERG, E.; SVANES, C.; OMENAAS, E.; NORRMAN, E.; JÕGI, R.; JENSEN, E. J.; DAHLMAN-HÖGLUND, A.; JANSON, C. Prevalence and incidence of respiratory symptoms in relation to indoor dampness: the RHINE study. Thorax, London, v. 61, p. 221-225, 2006.

HURRA $\beta$, J.; HEINZOW, B.; AURBACH, U.; BERGMANN, K.C.; BUFE, A.; BUZINA, W.; CORNELY, O. A.; ENGELHART, S.; FISCHER, G.; GABRIO, T.; HEINZ, W.; HERR, C. E. W.; KLEINETEBBE, J.; KLIMEK, L.; KÖBERLE, M.; LICHTNECKER, H.; LOB-CORZILIUS, T.; MERGET, R.; MÜLLENEISEN, N.; NOWAK, D.; RABE, U.; RAULF, M.; SEIDL, H. P.; STEIß, J.-O.; SZEWSZYK, R.; THOMAS, P.; VALTANEN, K.; WIESMÜLLER, G. A. Medical diagnostics for indoor mold exposure. International Journal of Hygiene and Environmental Health, New York, v. 220, p. 305-328, 2017.

LEVY, C. E. Detecção e identificação dos fungos de importância médica. In: SANTOS, A. A. M. dos (Coord.). Manual de Microbiologia Clínica para o controle de infecção em serviços de saúde. Brasília: Agência Nacional de Vigilancia Sanitária, 2004. p. 1-27.

LOSS, S. H.; ANTONIO, A. C. P.; ROEHRIG, C.; CASTRO, P. S.; MACCARI, J. G.; Meningite e endocardite infecciosa causada por Rhodotorula mucilaginosa em paciente imunocompetente. Revista Brasileira de Terapia Intensiva, São Paulo, v. 23, p. 507-509, 2011.

MEDINA, I. R.; FUENTES, L. R.; ARTEAGA, M. B.; VALCÁRCEL, F. R.; ARBELO, F. A.; DEL CASTILLO, D. P.; SUÁREZ, S. D.; QUINTANA, O. F.; GUTIÉRREZ, B. V.; SERGENT, F. S.; ACOSTA-HERNÁNDEZ, B. Pigeons and their droppings as reservoirs of Candida and other zoonotic yeasts. Revista Iberoamericana de Micología, Barcelona, v. 34, p. 211214, 2017.

MOLLOY, S. F.; CHILlER, T.; GREENE, G. S.; BURRY, J.; GOVENDER, N. P.; KANYAMA, C.; MFINANGA, S.; LESIKARI, S.; MAPOURE, Y. N;, KOUANFACK, C.; SINI, V.; TEMFACK, E.; BOULWARE, D. R.; DROMER, F.; DENNING, D. W.; DAY, J. STONE, N. R. H.; BICANIC, T.; JARVIS, J. N.; LORTHOLARY, O.; HARRISON, T. S.; JAFFAR, S.; LOYSE, A. Cryptococcal meningitis: a neglected NTD? PLOS Neglected Tropical Diseases, San Francisco, v. 11, e0005575, 2017.

NISHIKAWA, M. M.; LAZERA, M. S.; BARBOSA, G. G.; TRILLES, L.; BALASSIANO, B. R.; MACEDO, R. C. L.; BEZERRA, C. C. F.; PÉREZ, M. A.; CARDARELLI, P.; WANKE, B. Serotyping of 467 Cryptococcus neoformans isolates from clinical and environmental sources in Brazil: analysis of host and regional patterns. Journal of Clinical Microbiology, Washington, v. 41, p. 73-77, 2003.
PADOVAN, A. C. B.; MElO, A. S. de A.; COLOMBO, A. L. Systematic review and new insights into the molecular characterization of the Candida rugosa species complex. Fungal Genetics and Biology, Orlando, v. 61, p. 33-41, 2013.

PFALLER, M. A.; DIEKEMA, D. J.; GIBBS, D. L.; NEWELL, V. A.; NAGY, E.; DOBIASOVA, S.; RINALDI, M.; BARTON, R.; VESELOV, A.; FINQUELIEVICH, J.; TIRABOSCHI, N.; ELLIS, D.; FAMEREE, D.; VAN DEN ABEELE, A. M.; SENTERRE, J. M.; LOPEZ COLOMBO, A.; RENNIE, R.; SANCHE, S.; BIJIE, H.; XU, Y.; FU, W.; ZHONG, N. S.; RIVAS, P.; de BEDOUT, C.; MENDEZ, M.; VEGA, R.; MALLATOVA, N.; DOBIASOVA, S.; AYABACA, J.; ZURITA, J.; MALLIE, M.; CANDOLFI, E.; FEGELER, W.; HAASE, P. D. G.; RODLOFF, A.; BAR, W.; CZAIKA, V.; PETRIKOS, G.; PUSKÁS, E.; DÓCZI, I.; MESTYAN, G.; NIKOLOVA, R.; BANERJEE, U.; KELLER, N.; TULLIO, V.; CARLO SCHITO, G.; D’ANTONIO, D.; MARTINO, P.; PENG, N. K.; ALPUCHE, C.; SANTOS, J.; MORFIN ORTERO, R.; ZAIDI, M.; MEIS, J. F.; LINGAAS, E.; DZIERZANOWSKA, D.; PAWLISZYN, W.; LUZ MARTINS, M.; ALBUQUERQUE, L.; ROSADO, L.; VELHO, R.; AMORIM, J.; ILINA, V. N.; KRETCHIKOVA, O. I.; KLYASOVA, G. A.; ROZANOVA, S. M.; MULTYKH, I. G.; KLIMKO, N. N.; AGAPOVA, E. D.; DMITRIEVA, N. V.; AL RASHEED -, A. M.; SHIBL, A.; TRUPL, J.; HELENA, H.; HOOSEN, A.; WADULA, J.; JANSE VAN RENSBURG, M. N.; DUSE, A.; LEE, K.; KIM, M. N.; DEL PALACIO, A.; SANCHEZ-SOUSA, A.; BILLE, J.; MUHLETHALER, K.; CHANG, S. C.; WANG, J. H.; GUR, D.; KORTEN, V.; PAUL, J.; BROWN, D.; KIBBLER, C.; WEIGHTMAN, N.; GOULD, I. M.; RENNISON, C.; BARTON, R.; BARNES, R.; VAZQUEZ, J.; LARONE, D.; RINALDI, M.; REYES, H.; SANTIAGO, A. Candida krusei, a multidrug-resistant opportunistic fungal pathogen: Geographic and temporal trends from the ARTEMIS DISK Antifungal Surveillance Program, 2001 to 2005. Journal of Clinical Microbiology, Washington, v. 46, p. 515-521, 2008.

RAJASINGHAM, R.; SMITH, R. M.; PARK, B. J.; JARVIS, J. N.; GOVENDER, N. P.; CHILLER, T. M.; DENNING, D. W.; LOYSE, A.; BOULWARE, D. R. Global burden of disease of HIVassociated cryptococcal meningitis: an updated analysis. Lancet Infectious Diseases, Solna, v. 17, p. 873-881. 2017.

R CORE TEAM. R: a language and environment for statistical computing. 2013. Vienna: R Foundation for Statistical Computing. Disponível em: <https://www.R-project.org/>.

SALES, M. P. U. Chapter 5 - Aspergillosis: from diagnosis to treatment. Jornal Brasileiro de Pneumologia, Brasília, v. 35, p. 1238-1244, 2009. 